Article

\title{
Sick Leave and Factors Influencing Sick Leave in Adult Patients with Atopic Dermatitis: A Cross-Sectional Study
}

\author{
Harmieke van Os-Medendorp ${ }^{1, *}$, Simone Appelman-Noordermeer ${ }^{2}$, Carla Bruijnzeel-Koomen ${ }^{1}$ \\ and Marjolein de Bruin-Weller ${ }^{1}$
}

1 Department of Dermatology/Allergology, University Medical Centre Utrecht, Heidelberglaan 100, 3584CX Utrecht, The Netherlands; E-Mails: c.bruijnzeel@umcutrecht.nl (C.B.-K.); m.s.debruin-weller@umcutrecht.nl (M.B.-W.)

2 Student Clinical Health Sciences, University Medical Centre Utrecht, Heidelberglaan 100, 3584CX Utrecht, The Netherlands; E-Mail: sm_noor@hotmail.com

* Author to whom correspondence should be addressed; E-Mail: h.vanosmedendorp@umcutrecht.nl; Tel.: +31-88-7557-348.

Academic Editors: Sebastien Barbarot and Kim Thomas

Received: 5 December 2014 / Accepted: 16 February 2015 / Published: 27 March 2015

\begin{abstract}
Background: Little is known about the prevalence of sick leave due to atopic dermatitis (AD). The current literature on factors influencing sick leave is mostly derived from other chronic inflammatory diseases. This study aimed to determine the prevalence of sick leave due to AD and to identify influencing factors. Methods: A cross-sectional study was carried out in adult patients with AD. Outcome measures: sick leave during the two-week and one-year periods, socio-demographic characteristics, disease severity, quality of life and socio-occupational factors. Logistic regression analyses were used to determine influencing factors on sick leave over the two-week period. Results: In total, 253 patients were included; $12 \%$ of the patients had to take sick leave in the last two weeks due to $\mathrm{AD}$ and $42 \%$ in the past year. A higher level of symptom interference (OR 1.26; 95\% CI 1.13-1.40) or perfectionism/diligence (OR 0.90; 95\% CI 0.83-0.96) may respectively increase or decrease the number of sick leave days. Conclusion: Sick leave in patients with $\mathrm{AD}$ is a common problem and symptom interference and perfectionism/diligence appeared to influence it. Novel approaches are needed to deal with symptoms at work or school to reduce the amount of sick leave due to AD.
\end{abstract}


Keywords: atopic dermatitis; sick leave; influencing factors; quality of life; socio-occupational factors; severity

\section{Introduction}

Atopic dermatitis (AD) is a chronic skin disease with exacerbations and remissions which has a high impact on quality of life [1]. The overall prevalence of $\mathrm{AD}$ in general population is $2.3 \%$, with a higher prevalence of $11.3 \%$ under children up to six years [2].

Very few studies have analysed the impact of AD on the number of missed work days, and those that have show varying results. In a study in Denmark, the loss of work days due to AD was 5.8 days in a six-month period [3]. An international study showed that 2.7 days were lost per year due to work absence and $9.6 \%$ of work time was affected during flares [4]. In a Spanish study, the number of lost work days was 8.3 (sd 23.7) in one year [5]. Sick leave is not only inconvenient for the patient, it also incurs indirect economic costs $[4,6,7]$. These avoidable indirect economic costs for patients with AD were estimated at $€ 2$ billion per year across the EU [4].

To date, it is unclear which factors influence sick leave in patients with $\mathrm{AD}$ or other chronic diseases, and reports vary in their findings. The increasing effect of disease severity on sick leave was demonstrated in a cross-sectional study conducted in eight different countries in 2002 patients with $\mathrm{AD}$ [4] and in a study on 1673 patients with asthma in Spain [8]. In contrast, a study in the Netherlands by Boot et al. [9] reported that severity of disease was not a determinant of sick leave in asthma or COPD patients. For patients with psoriasis, it was also revealed that disease severity was not a predictor of productivity loss [10]. Other factors influencing sick leave in patients with chronic diseases are a low health-related quality of life $[9,10]$, poor disease control $[11,12]$ adaptation and psychosocial variables [13] and visits to health care providers [8].

The aim of this study is to demonstrate the extent of sick leave in the Netherlands due to AD and to explore factors that influence sick leave for these patients.

\section{Results}

\section{Patient Characteristics}

In total, 253 patients were included (Figure 1). The mean age of the study participants was 36.9 (sd 12.4) years; 66\% were female and most (49\%) had a high educational level. Other chronic diseases were present in $54 \%$ of all patients, of which allergies (44\%) and pulmonary diseases $(36 \%)$ were the most common. No differences were observed between the patients from the outpatient department and the patients' organization except for sex and educational level (Table 1). 


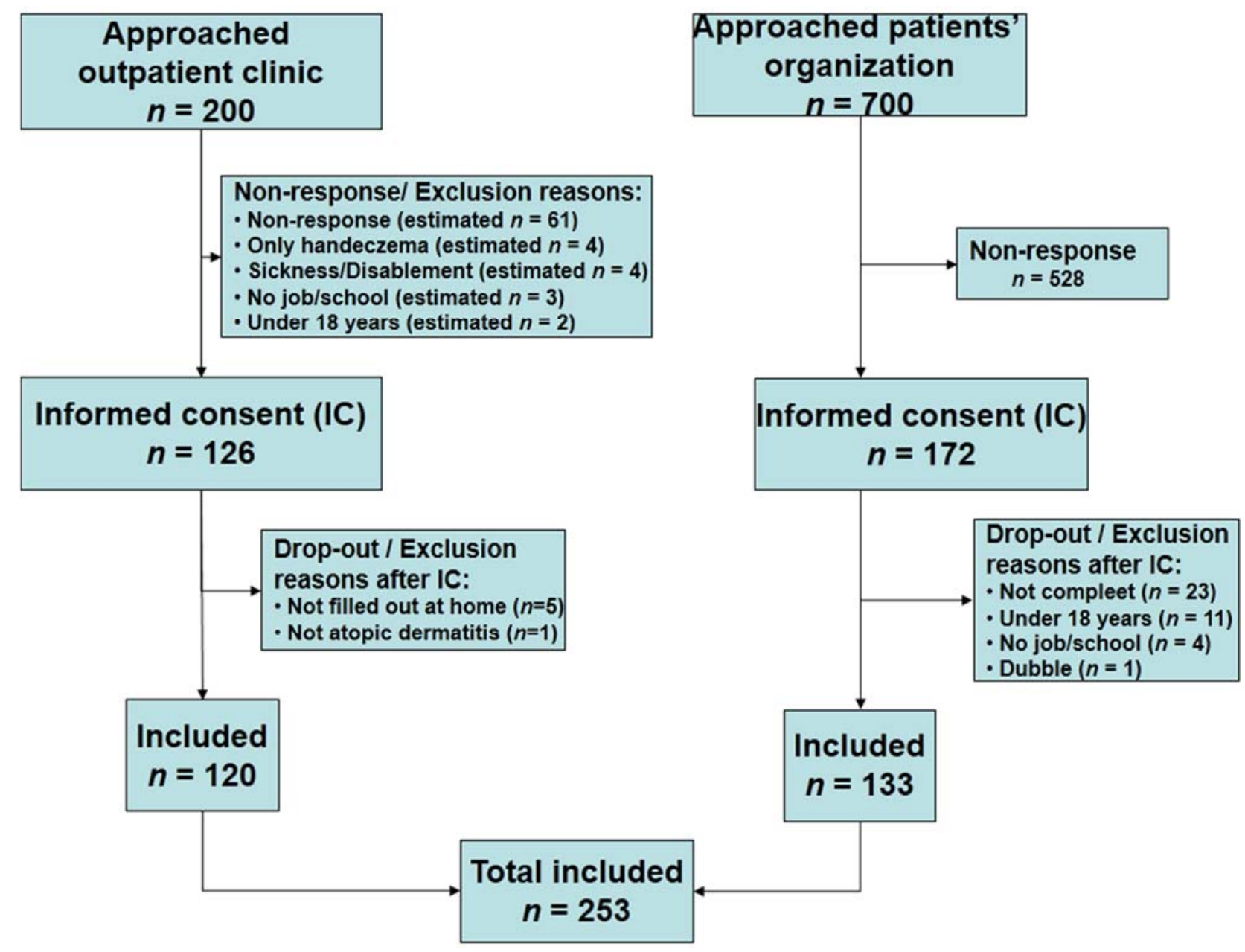

Figure 1. Flowchart inclusion process.

\section{Severity of AD, Quality of Life and Socio-Occupational Complaints}

The mean severity score of AD was 15.1 (sd 7.2); most patients had moderate (37\%) or severe $(35 \%)$ to very severe $(10 \%)$ AD. Of the study population, $44 \%$ had a severely impaired quality of life and $76 \%$ scored high on the symptoms subscale. Of the social-occupational subscores, $25 \%-42 \%$ patients displayed above mean or high scores for distress, work pressure, job dissatisfaction, little flexibility, stressful home situation, avoidance/uncertainty or perfectionism/diligence; $5 \%$ presented above mean or high scores on symptom interference (Table 2). Patients from the patients' organization scored higher on functioning, a subscale of quality of life. 
Table 1. Patient characteristics.

\begin{tabular}{|c|c|c|c|c|c|}
\hline \multicolumn{2}{|c|}{ Demographics } & $\begin{array}{l}\text { Total Group- } \\
\qquad n=253\end{array}$ & $\begin{array}{c}\text { Outpatient } \\
\text { Department- } \\
n=120 \\
\end{array}$ & $\begin{array}{c}\text { Patients' } \\
\text { Organization- } \\
n=133 \\
\end{array}$ & $\begin{array}{c}\text { Difference } \\
\text { Chi Square- } \\
\text { p/t-test-p }\end{array}$ \\
\hline \multirow{2}{*}{$\operatorname{Sex}(n, \%)$} & Man & $87(34)$ & $51(43)$ & $36(27)$ & 0.010 \\
\hline & Woman & $166(66)$ & $69(58)$ & $97(73)$ & \\
\hline Age (mean, sd) & & $\begin{array}{c}36.9(12.4)(n=252) \\
\text { range } 18-70\end{array}$ & $\begin{array}{l}36.3(13.3) \\
\text { range } 18-70\end{array}$ & $\begin{array}{c}37.3(11.4) \\
(n=132) \text { range } 18-65\end{array}$ & 0.52 \\
\hline $\begin{array}{l}\text { Disease duration } \\
\text { (mean in years, sd) }\end{array}$ & & $28.1(14.0)$ & $27.5(14.0)$ & $28.7(14.1)$ & 0.49 \\
\hline \multirow{3}{*}{ Education $(n, \%)$} & low & $29(12)$ & $21(18)$ & $8(6)$ & 0.000 \\
\hline & medium & $99(39)$ & $54(45)$ & $45(34)$ & \\
\hline & high & $125(49)$ & $45(38)$ & $80(60)$ & \\
\hline \multirow{3}{*}{$\begin{array}{c}\text { Work or } \\
\operatorname{school}(n, \%)\end{array}$} & school & $15(6)$ & $9(8)$ & $6(5)$ & 0.52 \\
\hline & work & $188(74)$ & $86(72)$ & $102(77)$ & \\
\hline & $\begin{array}{c}\text { combination } \\
\text { of work and } \\
\text { school }\end{array}$ & $50(20)$ & $25(21)$ & $25(19)$ & \\
\hline \multirow{2}{*}{$\begin{array}{c}\text { Other chronic } \\
\text { diseases }(n, \%)\end{array}$} & Yes & $137(54)$ & $68(57)$ & $69(52)$ & 0.45 \\
\hline & No & $116(46)$ & $52(43)$ & $64(48)$ & \\
\hline \multirow{2}{*}{$\begin{array}{c}\text { Other allergic } \\
\text { diseases (hay fever, } \\
\text { food allergy) }(n, \%)\end{array}$} & Yes & $112(44)$ & $55(46)$ & $57(43)$ & 0.63 \\
\hline & No & $141(56)$ & $65(54)$ & $76(57)$ & \\
\hline \multirow{2}{*}{ Pulmonary diseases } & Yes & $90(36)$ & $45(38)$ & $45(34)$ & 0.54 \\
\hline & No & $163(64)$ & $75(63)$ & $88(66)$ & \\
\hline
\end{tabular}

Table 2. Severity of AD, quality of life and socio-occupational complaints.

\begin{tabular}{|c|c|c|c|c|c|}
\hline Var & able & $\begin{array}{c}\text { Total } \\
\text { Group } \\
(n=253)\end{array}$ & $\begin{array}{c}\text { Outpatient } \\
\text { Department } \\
(n=120)\end{array}$ & $\begin{array}{c}\text { Patients' } \\
\text { Organization } \\
(n=133) \\
\end{array}$ & $\begin{array}{c}\text { Difference Chi } \\
\text { square-p/t-test-p }\end{array}$ \\
\hline \multicolumn{6}{|c|}{ Severity of Atopic Dermatitis } \\
\hline Severity (mean, sd) (POEM) & & $15.1(7.2)$ & $14.7(7.2)$ & $15.5(7.2)$ & 0.37 \\
\hline \multirow{5}{*}{ Severity $(n, \%)$} & Clear/almost clear (score 0-2) & $8(3.2 \%)$ & $5(4.2 \%)$ & $3(2.3 \%)$ & \\
\hline & Mild (score 3-7) & $36(14.2 \%)$ & $17(14.2 \%)$ & $19(14.3 \%)$ & \\
\hline & Moderate (score 8-16) & $94(37.2 \%)$ & $47(39.2 \%)$ & $47(35.3 \%)$ & \\
\hline & Severe (score 17-24) & $89(35.2 \%)$ & $41(34.2 \%)$ & $48(36.1 \%)$ & \\
\hline & Very severe (score 25-28) & $26(10.3 \%)$ & $10(8.3 \%)$ & $16(12.0 \%)$ & \\
\hline \multicolumn{6}{|c|}{ Quality of Life (Skindex 29) } \\
\hline \multirow{2}{*}{ Symptoms $(n, \%)$} & score $<52$ & $61(24)$ & $34(28)$ & $27(20)$ & 0.14 \\
\hline & score $\geq 52$ & $192(76)$ & $86(72)$ & $106(80)$ & \\
\hline \multirow{2}{*}{ Emotions $(n, \%)$} & score $<39$ & $138(55)$ & $62(52)$ & $76(57)$ & 0.38 \\
\hline & score $\geq 39$ & $115(46)$ & $58(48)$ & $57(43)$ & \\
\hline \multirow{2}{*}{ Functioning $(n, \%)$} & score $<37$ & $150(59)$ & $79(66)$ & $71(53)$ & 0.04 \\
\hline & Score $\geq 37$ & $103(41)$ & $41(34)$ & $62(47)$ & \\
\hline
\end{tabular}


Table 2. Cont.

\begin{tabular}{|c|c|c|c|c|c|}
\hline & ariable & $\begin{array}{c}\text { Total } \\
\text { Group } \\
(n=253)\end{array}$ & $\begin{array}{c}\text { Outpatient } \\
\text { Department } \\
(n=120)\end{array}$ & $\begin{array}{c}\text { Patients' } \\
\text { Organization } \\
(n=133) \\
\end{array}$ & $\begin{array}{c}\text { Difference Chi } \\
\text { square-p/t-test-p }\end{array}$ \\
\hline \multirow{2}{*}{ Overall score $(n, \%)$} & score $<44$ & $143(57)$ & $70(58)$ & $73(55)$ & 0.58 \\
\hline & Score $\geq 44$ & $110(44)$ & $50(42)$ & $60(45)$ & \\
\hline \multicolumn{6}{|c|}{ Social Occupational Complaints } \\
\hline \multirow{2}{*}{$\begin{array}{l}\text { Symptom interference } \\
\qquad(n, \%)\end{array}$} & low to mean score & $241(95)$ & $116(97)$ & $125(94)$ & 0.32 \\
\hline & above mean or high score $(\geq 31)$ & $12(5)$ & $4(3)$ & $8(6)$ & \\
\hline \multirow{2}{*}{ Distress $(n, \%)$} & low to mean score & $190(75)$ & $93(78)$ & $97(73)$ & 0.40 \\
\hline & above mean or high score $(\geq 29)$ & $63(25)$ & $27(23)$ & $36(27)$ & \\
\hline \multirow{2}{*}{ Work pressure $(n, \%)$} & low to mean score & $147(58)$ & $73(61)$ & $74(56)$ & 0.40 \\
\hline & above mean or high score $(\geq 16)$ & $106(42)$ & $47(39)$ & $59(44)$ & \\
\hline \multirow{2}{*}{ Job dissatisfaction $(n, \%)$} & low to mean score & $150(59)$ & $76(63)$ & $74(56)$ & 0.21 \\
\hline & above mean or high score $(\geq 26)$ & $103(41)$ & $44(37)$ & $59(44)$ & \\
\hline \multirow{2}{*}{ Little flexibility $(n, \%)$} & low to mean score & $159(63)$ & $70(58)$ & $89(67)$ & 0.16 \\
\hline & above mean or high score $(\geq 17)$ & $94(37)$ & $50(42)$ & $44(33)$ & \\
\hline \multirow{2}{*}{$\begin{array}{l}\text { Stressful home situation } \\
(n, \%)\end{array}$} & low to mean score & $182(72)$ & $88(73)$ & $94(71)$ & 0.64 \\
\hline & above mean or high score $(\geq 15)$ & $71(28)$ & $32(27)$ & $39(29)$ & \\
\hline \multirow{2}{*}{$\begin{array}{l}\text { Avoidance/uncertainty } \\
(n, \%)\end{array}$} & low to mean score & $172(68)$ & $85(71)$ & $87(65)$ & 0.36 \\
\hline & above mean or high score $(\geq 24)$ & $81(32)$ & $35(29)$ & $46(35)$ & \\
\hline \multirow{2}{*}{$\begin{array}{l}\text { Perfectionism/diligence } \\
\qquad(n, \%)\end{array}$} & low to mean score & $181(72)$ & $85(71)$ & $96(72)$ & 0.81 \\
\hline & above mean or high score $(\geq 37)$ & $72(29)$ & $35(29)$ & $37(28)$ & \\
\hline
\end{tabular}

\subsection{Prevalence of Sick Leave}

In total, $23 \%$ of patients took sick leave in the previous two weeks and $64 \%$ in the last year. Sick leave due to $\mathrm{AD}$ was $12 \%$ in the last two weeks and $42 \%$ in the last year. The mean number of days of sick leave due to $\mathrm{AD}$ in the previous two weeks was 0.3 ( $\mathrm{sd} \mathrm{0.9)}$ and 5.7 (sd 12.2) days in the last year (Table 3).

\subsection{Factors Influencing Sick Leave}

Univariate logistic regression analysis demonstrated that disease severity, quality of life and socio-occupational factors (symptom interference, distress, job dissatisfaction, stressful home situation, avoidance/uncertainty and perfectionism/diligence) were related to sick leave in the last two weeks $(p<0.2)$ (Table 4$)$. These factors were included in the final, multivariate regression. The full model was statistically significant ( chi $^{2} 52.5,8$ df, p. 0.00) and explained between 19 (Cox and Snell R square) and 37\% (Nagelkerke R square). The final model determined that a higher level of symptom interference, Odds Ratio (OR) 1.26 (95\% CI: 1.13-1.40) could increase the number of sick leave days, and higher scores on perfectionism/diligence could decrease the number of sick leave days, OR 0.90 (95\% CI: 0.83-0.96) (Table 5). 
Table 3. Prevalence of sick leave.

\begin{tabular}{|c|c|c|c|c|c|}
\hline Sick Leave & & $\begin{array}{l}\text { Total Group } \\
\qquad(n=253)\end{array}$ & $\begin{array}{c}\text { Outpatient } \\
\text { Department } \\
(n=120) \\
\end{array}$ & $\begin{array}{c}\text { Patients' } \\
\text { Organization } \\
(n=133) \\
\end{array}$ & $\begin{array}{c}\text { Difference } \\
\text { Chi2-p/t-test- } p\end{array}$ \\
\hline \multirow{2}{*}{$\begin{array}{c}\text { Sick leave in last } \\
\text { two weeks }\end{array}$} & No $n(\%)$ & $196(78)$ & $91(76)$ & $105(79)$ & 0.55 \\
\hline & Yes $n(\%)$ & $57(23)$ & $29(24)$ & $28(21)$ & \\
\hline \multirow{2}{*}{$\begin{array}{c}\text { Sick leave in last two weeks due } \\
\text { to AD }\end{array}$} & No $n(\%)$ & $222(88)$ & $104(87)$ & $118(89)$ & na \\
\hline & Yes $n(\%)$ & $29(12)$ & $15(13)$ & $14(11)$ & \\
\hline $\begin{array}{l}\text { Mean (sd) number of sick leave } \\
\text { days in last two weeks due to AD }\end{array}$ & & $\begin{array}{l}0.3(0.9) \\
(n=251)\end{array}$ & $\begin{array}{l}0.3(0.9) \\
(n=119)\end{array}$ & $0.2(0.8)(n=132)$ & 0.47 \\
\hline \multirow{2}{*}{$\begin{array}{l}\text { Sick leave } \\
\text { in last year }\end{array}$} & No $n(\%)$ & $90(36)$ & $44(37)$ & $46(35)$ & 0.73 \\
\hline & Yes $n(\%)$ & $163(64)$ & $76(63)$ & $87(65)$ & \\
\hline \multirow{2}{*}{$\begin{array}{l}\text { Sick leave in last } \\
\text { year due to } \mathrm{AD}\end{array}$} & No $n(\%)$ & $147(58)(n=252)$ & $67(56)$ & $80(61)$ & na \\
\hline & Yes $n(\%)$ & $105(42)$ & $53(44)$ & $52(39)$ & \\
\hline $\begin{array}{l}\text { Mean (sd) number of } \\
\text { sick leave days in } \\
\text { last year due to } \mathrm{AD}\end{array}$ & & $5.7(12.2)(n=252)$ & $7.1(15.0)$ & $4.4(8.6)(n=132)$ & 0.09 \\
\hline
\end{tabular}

na: Not assessed.

Table 4. Univariate analyses with factors influencing sick leave in the last two weeks.

\begin{tabular}{|c|c|c|c|}
\hline \multirow{2}{*}{$\begin{array}{c}\text { Influencing factor } \\
\text { Parameter }\end{array}$} & \multicolumn{3}{|c|}{ Sick Leave Days in Last Two Weeks $(n=251)$} \\
\hline & Wald ChiSquare Sig. & $\begin{array}{l}\text { Odds } \\
\text { Ratio }\end{array}$ & $\begin{array}{l}\text { 95\% Wald Confidence Interval } \\
\text { for Odds Ratio Lower-Upper }\end{array}$ \\
\hline \multicolumn{4}{|c|}{ Socio demographics } \\
\hline Age & 0.53 & 0.99 & $0.96-1.02$ \\
\hline Sex & 0.22 & 1.63 & $0.74-3.56$ \\
\hline Disease duration & 0.89 & 1.00 & $0.98-1.03$ \\
\hline Other chronic diseases & 0.74 & 1.14 & $0.53-2.47$ \\
\hline Numbers of days of work and school per week & 0.92 & 0.98 & $0.72-1.34$ \\
\hline Medium educational level & 0.89 & 0.91 & $0.24-3.47$ \\
\hline High educational level & 0.99 & 0.99 & $0.26-3.72$ \\
\hline \multicolumn{4}{|c|}{ Disease Severity and Quality of Life } \\
\hline Disease severity & 0.08 & 1.05 & $1.00-1.11$ \\
\hline Quality of life (total score) & 0.00 & 1.05 & $1.02-1.07$ \\
\hline Quality of life—-subscale symptoms & 0.02 & 1.03 & $1.00-1.05$ \\
\hline Quality of life—subscale emotions & 0.00 & 1.03 & $1.01-1.05$ \\
\hline Quality of life-subscale functioning & 0.00 & 1.04 & $1.02-1.07$ \\
\hline \multicolumn{4}{|c|}{ Socio Occupational Factors } \\
\hline Symptom interference & 0.00 & 1.22 & $1.14-1.32$ \\
\hline Distress & 0.00 & 1.10 & $1.04-1.15$ \\
\hline Work pressure & 0.92 & 1.00 & $0.93-1.09$ \\
\hline Job dissatisfaction & 0.00 & 1.08 & $1.02-1.13$ \\
\hline Little flexibility & 0.61 & 1.02 & $0.94-1.11$ \\
\hline Stressful home situation & 0.00 & 1.14 & $1.05-1.24$ \\
\hline Avoidance/uncertainty & 0.00 & 1.09 & $1.03-1.15$ \\
\hline Perfectionism/diligence & 0.07 & 0.95 & $0.90-1.00$ \\
\hline
\end{tabular}


Table 5. Factors influencing sick leave in the last two weeks based on logistic regression.

\begin{tabular}{cccc}
\hline Parameter $(\boldsymbol{n}=\mathbf{2 5 1})$ & $\begin{array}{c}\text { Wald } \\
\text { ChiSquare Sig. }\end{array}$ & $\begin{array}{c}\text { Odds } \\
\text { Ratio }\end{array}$ & $\begin{array}{c}\text { 95\% Wald Confidence Interval } \\
\text { for Odds Ratio Lower-Upper }\end{array}$ \\
\hline (Intercept) & 0.00 & 0.01 \\
\hline Disease severity & 0.08 & 0.93 \\
Quality of life-total score & 0.51 & 1.02 & $0.85-1.01$ \\
\hline \multicolumn{4}{c}{ Disease Severity and Quality of Life } \\
\hline Symptom interference & 0.00 & 1.26 & $0.97-1.06$ \\
Distress & 0.91 & 1.00 & $0.13-1.40$ \\
Job dissatisfaction & 0.63 & 1.02 & $0.95-1.08$ \\
Stressful home situation & 0.14 & 1.08 & $0.98-1.19$ \\
Avoidance/uncertainty & 0.71 & 1.02 & $0.93-1.11$ \\
Perfectionism/diligence & 0.00 & 0.90 & $0.83-0.96$ \\
\hline
\end{tabular}

\section{Discussion}

In this study of adult patients with moderate to severe $\mathrm{AD}$, we showed that $12 \%$ of them took sick leave due to $\mathrm{AD}$ in the previous two weeks (mean number of days 0.3 , sd 0.9 ) and $42 \%$ (mean number of days 5.7, sd 12.2) in the past year. Of all patients, $44 \%$ had severely impaired quality of life. Also, $25 \%-42 \%$ showed above mean or high scores on socio-occupational factors. Results indicated that the number of days of sick leave was influenced by a higher level of symptom interference (consisting of influence of severity of complaints on work performance, need of rest, and perceived threshold for return to work), while higher scores on perfectionism/diligence could decrease the number of days of sick leave.

In the Netherlands, about 50\% of all employees took sick leave per year [14], with a mean of 7.5 days a year, which is lower than the $64 \%$ of this population of AD patients reporting sick leave in the last year. Findings about the number of sick leave days in AD patients differ between published studies. AD patients in this study averaged 5.7 days/year of sick leave compared with lower number of sick leave days in an international [4] and a Canadian study [7]. Two other studies in Denmark and Spain showed a higher number of sick leave days in AD patients [3,5]. Differences in results appear to be attributed to variations in methodology. Data collection included self-reporting questionnaires from our study, the international study with eight countries, the Spanish and Canadian studies [4,5,7] as well as from public resources as in the Danish study [3]. Recall bias may have influenced the precision of the self-reported data about the number of lost work days, especially for information over a longer time period [15]. In addition, the severity of $\mathrm{AD}$ of the study population was measured using different tools such as a subjective grading [3,5,7] or physician's grading [4], which limits comparison between studies.

Based on the results of the univariate analysis, sick leave was influenced both by severity of AD and symptom interference. Multivariate analyses demonstrated that higher symptom interference increases sick leave, and that severity of $\mathrm{AD}$ does not. This may be explained by the significant correlation (Pearson's $r$ : 0.56) between both variables. Multivariate analyses without severity of AD decreases the explained variance of the model with only $1 \%$, but in multivariate analyses without 
symptom interference, the explained variance decreased from 19 to $12 \%$ (Cox and Snell $\mathrm{R}$ square) and from 37 to $23 \%$ (Nagelkerke $\mathrm{R}$ square). Therefore, we conclude that symptom interference, which is determined by the influence of disease complaints on work performance, is a better predictor for sick leave than disease severity. This is consistent with the findings of a study in asthma patients which reported that perception of health complaints during social activities increases sick leave [13]. It has been shown that subjective health complaints also increase sick leave in a general working population $[16,17]$.

We observed a novel correlation between perfectionism/diligence and sick leave: perfectionism/ diligence could slightly decrease sick leave. Although this particular relationship has not been reported in literature concerning chronic somatic diseases, other factors such as disease control and quality of life were related to sick leave in patients with asthma, psoriasis or COPD [8-10,12]. Further research is needed to explain the relationship between sick leave and factors such as perfectionism and symptom interference in patients with $\mathrm{AD}$.

The study population consisted of patients visiting an outpatient department of a university hospital and members or visitors to the website of a patient organization. No significant differences were observed between the two groups regarding disease severity, quality of life and socio-occupational complaints, except for daily functioning (such as sleep, social life and work). AD patients from the patients' organization scored higher scores in the daily functioning scale, meaning a higher negative impact. The severity (POEM) scores indicate that our study population was representative of patients with moderate to severe $\mathrm{AD}$ [18]. However, the diagnosis of $\mathrm{AD}$ in patients recruited by the website was reported by the patients themselves and not confirmed by a medical doctor for this study. Besides, response rates were low; 63\% (126/200) of the approached patients of the outpatient department gave informed consent while only $25 \%(172 / 700)$ of the people from the patients' organization did so. Reasons for non-response were often unknown, especially in the group of the patients' organization. All members of the patients' organization with a known email address were approached for participation, but about $25 \%$ of them were parents of children with $\mathrm{AD}$ and they did not fulfil the inclusion criterion concerning adult patients with AD. It is also possible that approached members did not work or attend school and therefore also did not fulfil the inclusion criteria. However, the data suggest that patients who experience greater impact from $\mathrm{AD}$ in daily life responded more often because $47 \%$ of participants from the patient organization had high scores on the functioning scale of quality of life. Therefore selection bias cannot be ignored, leading to a study population with a higher burden of AD.

The study had a cross sectional design and data were collected for a previous time period, which could have led to recall bias and less reliable results. Moreover, the study may be insufficient to determine influencing factors, since only a minority of patients had sick leave days in the last two weeks. Therefore a prospective design with a larger sample is recommended for further research.

We conclude that sick leave is a common problem in patients with AD. No clear relationship was found between sick leave and disease severity, but symptom interference, the influence of AD complaints on work performance and perfectionism/diligence seemed to influence the amount of sick leave. Since sick leave and loss of productivity during work both contribute to indirect costs of a disease [16], this study highlights the importance of investigating novel approaches to dealing with symptoms at work or school. 


\section{Materials and Methods}

\subsection{Design}

A cross-sectional study design was carried out between January and March 2012.

\subsection{Study Population:}

The target population of this study was adult patients with AD. Patients were included if they were diagnosed with $\mathrm{AD}$, were aged 18 years or older, worked or attended school, and had the ability to read or speak Dutch. Patients were recruited at the Dermatology outpatient department of the University Medical Centre Utrecht, The Netherlands, as well as through the website of the Dutch association for patients with AD (VMCE).

\subsection{Outcome Variables and Instruments}

SICK LEAVE: Patients were asked if they took sick leave either in the previous two weeks or year. In addition, they were specifically asked for the number of days of sick leave from work and/or school taken in the previous two weeks and year.

SOCIO-DEMOGRAPHIC FACTORS: These factors were measured by self-reporting about gender, age, educational level, disease duration, other chronic diseases and career.

SOCIO-OCCUPATIONAL FACTORS: The Dutch Work Reintegration Questionnaire [19] measured these factors, which included subscales for the variables distress (sleep behaviour, tiredness, depressive symptoms, distress complaints, appetite); symptom interference (influence of severity of complaints on work performance, need of rest, perceived threshold for return to work); work pressure (job demands, emotional burden, balance home-work); little flexibility (scheduling work tasks, breaks, work pace); job dissatisfaction (work experience, job content, working conditions, social support of manager and colleagues,); avoidance/uncertainty (avoidance behaviour, uncertainty); perfectionism/ diligence (handling limits, setting high demands, diligence) and stressful home situation (stressful life events, daily stress). The questionnaire consisted of 78 claims about a patient's current situation with a four-point Likert-scale (not, sometimes, often, usually). Total score were calculated, and a higher score meant the patient experienced problems more frequently within the concerning variable [20]. For the variable "little flexibility" a higher score should be interpreted as less flexibility. The questionnaire has a high internal consistency and a good test-retest reliability [20,21].

QUALITY OF LIFE: These factors were measured by the Skindex-29 (SD-29) [22,23], which consists of the subscales symptoms, emotions and daily functioning. Patients were asked 30 questions about the previous week on a five-point Likert-scale (never, rarely, sometimes, often, always). Higher scores signify a more severe negative impact on the quality of life [24]. The Skindex-29 has moderate to good psychometric properties [25,26].

DISEASE SEVERITY: Disease severity was measured by the Patient-Oriented Eczema Measure (POEM) [27,28]. The questionnaire consisted of seven questions about the previous week with a five-point Likert-scale answer possibility (0 days, 1-2 days, 3-4 days, 5-6 days, all days of the week). A higher total score indicates a higher disease severity, with a maximum total score of 28. 
The questionnaire has moderate to good psychometric properties [27] and moderate sensitivity to change [28].

Data were collected via a questionnaire to be completed either on the computer or on paper.

\subsection{Data Analysis}

DESCRIPTIVES: Number (percentage) of patients who took sick leave in the previous two weeks or last year, as well as the number of days of sick leave due to AD (mean, sd) were described. In cases in which the amount of lost days in the previous two weeks was higher than that of the previous year, the amount of lost days in the previous year was calculated by the sum of the amount of lost days in the previous two weeks and that of the previous year. Socio-demographic characteristics are presented as descriptives or frequencies. The scores of the eight subscales of the Work Reintegration Questionnaire were dichotomized and depicted as percentages of patients with low to mean scores and above mean scores, based on a table with standard scores of Dutch employees who took sick leave [19]. Above mean scores for the subscales are: distress $\geq 29$; symptom interference $\geq 31$; work pressure $\geq 16$; little flexibility $\geq 17$; job dissatisfaction $\geq 26$; avoidance/uncertainty $\geq 24$; perfectionism/diligence $\geq 37$ and stressful home situation $\geq 15$. Scores on the Skindex-29 were also dichotomized, based on cut-off scores for severely impaired health related quality of life [23]. The cut-off scores are for the subscale symptoms $\geq 52$, emotions $\geq 39$, functioning $\geq 37$, and for the overall score $\geq 44$ points. The total scores of POEM were presented as mean (sd) total score and range. Severity range was based on proposed banding [18] in clear/almost clear (score 0-2); mild (score 3-7); moderate (score 8-16); severe (score 17-24); very severe (score 25-28).

LOGISTIC REGRESSION: Logistic regression was used to analyse predictors of sick leave at work or school in the last two weeks in patients with $\mathrm{AD}$. Factors used for modelling the regression equation were selected by univariate logistic regression. Factors with a significance level of $p \leq 0.20$ were used in the multivariate logistic regression. All analyses were conducted with IBM SPSS statistics 20. Only completed questionnaires were included in the analyses.

SAMPLE SIZE: A sample size of 270 patients provided reliable evidence for the primary research question based on a $95 \%$ confidence level; a response distribution of 50\%; an estimated eligible, population size of 900 ; and a $5 \%$ margin of error [29].

\subsection{Ethical Approval}

All patients were carefully informed about the study and gave their informed consent. The study was not covered by the Medical Research Involving Human Subjects Act which was confirmed by the Medical Research Ethics Committee of the UMC Utrecht, the Netherlands (protocol number $11-556 / \mathrm{C})$.

\section{Conclusions}

Sick leave in patients with AD is a common problem and symptom interference and perfectionism/ diligence appeared to influence it. Novel approaches are needed to deal with symptoms at work or school to reduce the amount of sick leave due to AD. 


\section{Acknowledgments}

The authors would like to thank Bernd Arents of the Dutch Association for Patients with AD for his help in patient recruitment. Research was funded by the University Medical Centre (UMC) Utrecht, the Netherlands. The UMC Utrecht had no role in the design of the study; in the collection, analyses, or interpretation of data; in the writing of the manuscript; or in the decision to publish the results.

\section{Author Contributions}

Harmieke van Os-Medendorp, Simone Appelman-Noordermeer and Marjolein de Bruin-Weller designed the study; Harmieke van Os-Medendorp and Simone Appelman-Noordermeer collected and analysed data. All authors interpreted the results; Harmieke van Os-Medendorp and Simone Appelman-Noordermeer wrote the manuscript; all authors contributed to final writing and discussion of the manuscript.

\section{Conflicts of Interest}

The authors declare no conflict of interest.

\section{References}

1. Eichenfield, L.F.; Tom, W.L.; Chamlin, S.L.; Feldman, S.R.; Hanifin, J.M.; Simpson, E.L.; Berger, T.G.; Bergman, J.N.; Cohen, D.E.; Cooper, K.D.; et al. Guidelines of care for the management of atopic dermatitis: Section 1. Diagnosis and assessment of atopic dermatitis. J. Am. Acad. Dermatol. 2014, 70, 338-351.

2. Verboom, P.; Hakkaart-Van, L.; Sturkenboom, M.; de Zeeuw, R.; Menke, H.; Rutten, F. The cost of atopic dermatitis in the Netherlands: An international comparison. Br. J. Dermatol. 2002, 147, 716-724.

3. Holm, E.A.; Esmann, S.; Jemec, G.B. The handicap caused by atopic dermatitis—Sick leave and job avoidance. J. Eur. Acad. Dermatol. Venereol. 2006, 20, 255-259.

4. Zuberbier, T.; Orlow, S.J.; Paller, A.S.; Taieb, A.; Allen, R.; Hernanz-Hermosa, J.M.; Ocampo-Candiani, J.; Cox, M.; Langeraar, J.; Simon, J.C. Patient perspectives on the management of atopic dermatitis. J. Allergy Clin. Immunol. 2006, 118, 226-232.

5. Torrelo, A.; Ortiz, J.; Alomar, A.; Ros, S.; Prieto, M.; Cuervo, J. Atopic dermatitis: Impact on quality of life and patients' attitudes toward its management. Eur. J. Dermatol. 2012, 22, 97-105.

6. Fowler, J.F.; Duh, M.S.; Rovba, L.; Buteau, S.; Pinheiro, L.; Lobo, F.; Sung, J.; Doyle, J.J.; Swensen, A.; Mallett, D.A.; et al. The direct and indirect cost burden of atopic dermatitis: An employer-payer perspective. Manag. Care Interface 2007, 20, 26-32.

7. Barbeau, M.; Bpharm, H.L. Burden of Atopic dermatitis in Canada. Int. J. Dermatol. 2006, 45, 31-36.

8. Gonzalez Barcala, F.J.; la Fuente-Cid, R.D.; Alvarez-Gil, R.; Tafalla, M.; Nuevo, J.; Caamano-Isorna, F. Factors associated with a higher prevalence of work disability among asthmatic patients. J. Asthma 2011, 48, 194-199. 
9. Boot, C.R.; van der Gulden, J.W.; Orbon, K.H.; Vercoulen, J.H.; Akkermans, R.; van Weel, C.; Folgering, H.T. Asthma and chronic obstructive pulmonary disease: Differences between workers with and without sick leave. Int. Arch. Occup. Environ. Health 2004, 77, 357-362.

10. Schmitt, J.M.; Ford, D.E. Work limitations and productivity loss are associated with health-related quality of life but not with clinical severity in patients with psoriasis. Dermatology 2006, 213, $102-110$.

11. Boot, C.R.; Vercoulen, J.H.; van der Gulden, J.W.; van den Borne, B.H.; Orbon, K.H.; van Weel, C.; Folgering, H.T. Sick leave in workers with asthma and COPD: The role of attitudes, perceived social norms and self efficacy. Patient Educ. Couns. 2005, 58, 192-198.

12. Accordini, S.; Bugiani, M.; Arossa, W.; Gerzeli, S.; Marinoni, A.; Olivieri, M.; Pirina, P.; Carrozzi, L.; Dallari, R.; de Togni, A.; et al. Poor control increases the economic cost of asthma. A multicentre population-based study. Int. Arch. Allergy Immunol. 2006, 141, 189-198.

13. Boot, C.R.; Vercoulen, J.H.; van der Gulden, J.W.; Orbon, K.H.; Rooijackers, J.M.; van Weel, C.; Folgering, H.T. Predictors of changes in sick leave in workers with asthma: A follow-up study. Int. Arch. Occup. Environ. Health 2005, 78, 633-640.

14. TNO. Ziekteverzuim in Nederland in 2010. Available online: http://www.rijksoverheid.nl/ documenten-en-publicaties/brochures/2012/03/19/ziekteverzuim-in-nederland-in-2010.html (accessed on 1 May 2014)

15. Mann, C.J. Observational research methods. Research design II: Cohort, cross sectional, and case-control studies. Emerg. Med. J. 2003, 20, 54-60.

16. Roelen, C.A.; Koopmans, P.C.; Groothoff, J.W. Subjective health complaints in relation to sickness absence. Work 2010, 37, 15-21.

17. Poulsen, O.M.; Persson, R.; Kristiansen, J.; Andersen, L.L.; Villadsen, E.; Orbaek, P. Distribution of subjective health complaints, and their association with register based sickness absence in the Danish working population. Scand. J. Public Health 2013, 41, 150-157.

18. Charman, C.R.; Venn, A.J.; Ravenscroft, J.C.; Williams, H.C. Translating Patient-Oriented Eczema Measure (POEM) scores into clinical practice by suggesting severity strata derived using anchor-based methods. Br. J. Dermatol. 2013, 169, 1326-1332.

19. Vendrig, A. A Vragenlijst Arbeidsreintegratie. Available online: http://vendrig.praktijkinfo.nl/ pagina/33/materialen-var/ (accessed on 1 May 2013).

20. Vendrig, L. Risico op langdurig verzuim onderzocht met de Vragenlijst ArbeidsReïntegratie (VAR). Tijdschr. Gezondh. 2007, 85, 386-391.

21. Vendrig, L. De vragenlijst arbeidsreintegratie. Diagn. Wijzer 2005, 8, $27-39$.

22. Chren, M.M.; Lasek, R.J.; Quinn, L.M.; Mostow, E.N.; Zyzanski, S.J. Skindex, a quality-of-life measure for patients with skin disease: Reliability, validity, and responsiveness. J. Investig. Dermatol. 1996, 107, 707-713.

23. Prinsen, C.A.; Lindeboom, R.; Sprangers, M.A.; Legierse, C.M.; de Korte, J. Health-related quality of life assessment in dermatology: Interpretation of Skindex-29 scores using patient-based anchors. J. Investig. Dermatol. 2010, 130, 1318-1322.

24. Stichting Aquamarijn Handleiding Nederlandstalige Skindex-29; Een dermatologiespecifieke kwaliteit-van-leven vragenlijst. Available online: http://www.scribd.com/doc/1186801/ skindex-handleiding (accessed on 1 May 2013). 
25. Chren, M.M.; Lasek, R.J.; Flocke, S.A.; Zyzanski, S.J. Improved discriminative and evaluative capability of a refined version of Skindex, a quality-of-life instrument for patients with skin diseases. Arch. Dermatol. 1997, 133, 1433-1440.

26. Chren, M.M. The Skindex instruments to measure the effects of skin disease on quality of life. Dermatol. Clin. 2012, 30, 231-236.

27. Charman, C.R.; Venn, A.J.; Williams, H.C. The patient-oriented eczema measure: Development and initial validation of a new tool for measuring atopic eczema severity from the patients' perspective. Arch. Dermatol. 2004, 140, 1513-1519.

28. Schram, M.E.; Spuls, P.I.; Leeflang, M.M.; Lindeboom, R.; Bos, J.D.; Schmitt, J. EASI, (objective) SCORAD and POEM for atopic eczema: Responsiveness and minimal clinically important difference. Allergy 2012, 67, 99-106.

29. Raosoft Sample size calculator, 2004. Available online: http://www.raosoft.com/samplesize.html (accessed on 1 January 2012).

(C) 2015 by the authors; licensee MDPI, Basel, Switzerland. This article is an open access article distributed under the terms and conditions of the Creative Commons Attribution license (http://creativecommons.org/licenses/by/4.0/). 